University of Michigan Law School

University of Michigan Law School Scholarship Repository

\title{
Christianity and the International Economic Order
}

\author{
Daniel A. Crane \\ University of Michigan Law School, dancrane@umich.edu
}

Available at: https://repository.law.umich.edu/book_chapters/218

Follow this and additional works at: https://repository.law.umich.edu/book_chapters

Part of the Christianity Commons, and the Law and Economics Commons

\section{Publication Information \& Recommended Citation}

Crane, Daniel A. "Christianity and the international economic order." In Christianity and Global Law, edited by Rafael Domingo and John Witte, Jr., 337-50. Law and Religion. New York: Routledge, 2020.

This Book Chapter is brought to you for free and open access by the Faculty Scholarship at University of Michigan Law School Scholarship Repository. It has been accepted for inclusion in Book Chapters by an authorized administrator of University of Michigan Law School Scholarship Repository. For more information, please contact mlaw.repository@umich.edu. 


\section{CHRISTIANITY AND GLOBAL LAW}

Edited by

Rafael Domingo and John Witte, Jr. 


\section{Christianity and Global Law}

\section{Edited by Rafael Domingo and John Witte, Jr.}

Produced by the Center for the Study of Law and Religion, Emory University

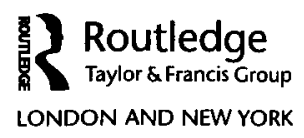




\title{
20 Christianity and the international economic order
}

\author{
Daniel A. Crane
}

It is difficult to feel much optimism about the future of the global economic order. As this chapter is being written, Great Britain is fighting to extricate itself from the European Union, the United States is repudiating its longtime championship of multilateral free trade agreements, and the long-standing "Washington consensus" around the neoliberal policies epitomized by such institutions as the International Monetary Fund (IMF), the World Bank, and the General Agreement on Tarifts and Trade (GATT) seems to be disintegrating. A global order that just a few years ago seemed to be increasingly united and homogenized by the internet, economic globalization, and the movement toward market democracy is threatening to fall apart under the centrifugal forces of nationalism, localism, and political alienation. It may be too early to sound warning bells about the global disintegration that preceded the rise of fascism and the Second World War, but current trend lines are not looking promising for Thomas Friedman's "Golden Arches" theory of conflict prevention-that no two countries that had McDonald's restaurants would ever go to war.

The pressures bearing down on the global economic order come from multiple directions. On the political right, demands to preserve traditional prerogatives of national sovereignty and autonomy and to reject multiculturalism and internationalism are driving to erect (or reerect) economic border walls. ${ }^{1}$ On the political left, criticisms have mounted against the Washington consensus or neoliberalism that was seen as serving corporatist rather than indigenous interests and, particularly, serving up a new form of colonialism to the developing world. ${ }^{2}$ It is increasingly difficult to find robust defenders of economic globalism outside of technocratic elites that seem to be routed by a populist tidal wave of nationalism and localism.

Amid this doom and gloom for globalism, what does the church have to offer beyond platitudes concerning the need to construct a just and equitable system that works for all? Should the church focus its efforts on influencing political leaders to redouble efforts to preserve the global economic order through the force of treaties, laws, and regulations? Should it instead accept the reversion to economic nationalism as inevitable and perhaps even respectfil of national sovereignty, and refocus its efforts on domestic economic justice? Or, more radically, should the church look beyond the global economic order as a system created 


\section{8}

and maintained by public law and adopt strategies to influence the global economic system directly as a deliberate market participant? There is no consensus Christian answer to these questions, although much material in the Christian tradition bears on all of them.

\section{Christian ideology and the global economy}

Christian thinkers have long contributed to the development of economic theory in important ways. For example, scholastic theorists wrote extensively on such matters as money lending, just pricing, sales, leases, and partnership contracts; ${ }^{3}$ natural law theorists like Samuel von Pufendorf and Hugo Grotius contributed to the intellectual foundations of international trade; ${ }^{4}$ and Reformation figures like Martin Luther developed bodies of teachings on usury and monopoly. ${ }^{5}$ But the present question is to what extent the contemporary international economic order, reflecting a general orientation toward regulated market capitalism, reflects Christian theological, moral, and dogmatic influences.

Historically speaking, there is little doubt that aspects of Christian ideology have significantly shaped the contemporary international economic order, although scholars often disagree on just how it has done so. Rodncy Stark has argued that Christianity, by focusing on theological abstraction and rationality and recognizing property and contract rights, became a catalyst for technological and scientific innovation throughout Western Europe. ${ }^{6}$ Joel Mokyr has disputed what he views as Stark's "argument based on some inherent superiority of Western or Christian culture" in advancing technological innovation, but does credit the Puritan embrace of science as the impetus behind the British Industrial Revolution. ${ }^{7}$ Empirical work has shown that the spread of Protestantism following the Reformation had significant economic effects on human capital, economic development, competition in media markets, and political economy. ${ }^{8} \mathrm{Max}$ Weber famously credited Protestantism and its rigorous work ethic with the creation of capitalism, which underlies the economic globalization that has occurred since the fall of the Berlin Wall, and Adam Smith-theologically a Deist but heavily influenced by Scottish Presbyterianism-laid the intellectual foundations of free-market systems. ${ }^{9}$ Christian thought is often said to undergird the rise of capitalism. ${ }^{10}$

While Christian thinkers and systems of Christian thought have undoubtedly shaped the global economic order, it would be difficult to sustain the claim that the international economic system portrays a Christian image, for the simple reason that it would be difficult to find any five randomly selected priests or ten randomly selected pastors who would concur on what a Christian economic system should resemble. It bears remembering that, in the twentieth century alone, Christians were willing to go to war over whether liberation theology and its Marxist dogma or liberal capitalism better epitomized the message of the cross. Given that prominent Christian leaders like William Temple, the Archbishop of Canterbury, could assert that Marxism was the only viable economic theory for Christians to accept, ${ }^{1}$ and theologians like Paul Tillich and Reinhold Neibuhr 
could (at least at one point in their careers) largely assent to Karl Barth's declaration that "a real Christian must become a socialist [and] a real socialist must become a Christian" and that "anti-Communism [is] as a matter of principle an even greater evil than Communism itself," 12 it would seem presumptuous to equate the global capitalist order with Christian theology-whatever any individual Christian's views on the merits.

At most, the global economic order reflects the influence of various strands of Christian thought. While any number of thinkers have attempted to justify a comprehensive economic theory on biblical principles, the intellectual lineage of global capitalism is primarily traceable to a Western European Enlightenment tradition that drew on many Christian influences, but also on many skeptical ones. The agnosticism or skepticism of leading proponents of laissez-faire systems like Adam Smith, Herbert Spencer, and John Stuart Mill should give us pause before dubbing global capitalism the offspring of Christendom. Rather than attempting to understand the global economic order as the intellectual offspring of any single faith tradition, it is probably more relevant to consider the interventions that the church has made on concrete institutions, rules, and principles of the international economic order.

Beyond the particulars of Christian theology, there are interesting questions around the effects of Christian beliefs on economic growth and development within different populations around the globe. Empirical evidence suggests crosscutting effects for different manifestations of Christian belief. A 2003 study by the National Bureau of Economic Research (NBER) found that increases in church attendance tend to reduce economic growth because church attendance is correlated with a greater use of economic resources by the religious sector (and the authors were studying mostly Christian-majority countries), but that some particular religious beliefs-heaven, hell, and an afterlife-tend to increase economic growth because they sustain various behaviors that enhance productivity. ${ }^{13}$ The authors interpreted these results as suggesting that "growth depends on the extent of believing relative to belonging." Christian beliefs may have a positive effect on the growth of the global economy, even while church attendance may seem, empirically, like a drag on economic growth. Christian beliefs and practices are thus exerting an influence on the global economic order, but the sign and magnitude of their influence is difficult to pin down.

\section{The global order and public law}

When people speak of the global economic order, they usually have in mind the formal system of treaties, laws, regulations, and institutions created by public international law and public domestic law focused on international economic dealings. A leading list of such institutions would include the World Trade Organization (WTO), an intergovernmental organization policing trade agreements among member states; the European Union, the political and economic union of (a shrinking) number of member states; and the IMF, an association of 189 countries ostensibly working to foster global monetary cooperation, secure 
financial stability, facilitate international trade, promote high employment and sustainable economic growth, and reduce poverty around the world. There are also many international institutions of "soft law," such as the Basel Accords on banking regulation, which since 1988 have resulted in a series of recommendations to national banking authorities on how to manage such issues as capital adequacy risk, bank supervision, financial disclosure, and liquidity ratios. At a yet less formally structured level, cooperation among national regulatory authorities on matters such as antitrust and securities regulation through a variety of bilateral or multilateral cooperation and information-sharing agreements contributes to the creation of a global economic order structured and policed by the force of law.

The church's role in shaping this formal economic order is largely hortatory. The church, or individual Christians, can attempt to influence political decisionmakers to adopt ethical and moral principles, as they can on any matter of public policy. And they have done so. For example, Pope Benedict XVI's encyclical letter Caritas in veritate excoriated the excesses of individualistic global capitalism and called for a humane and fraternal vision for economic globalism:

Sometimes globalization is viewed in fatalistic terms, as if the dynamics involved were the product of anonymous impersonal forces or structures independent of the human will. In this regard it is useful to remember that while globalization should certainly be understood as a socio-economic process, this is not its only dimension. Underneath the more visible process, humanity itself is becoming increasingly interconnected; it is made up of individuals and peoples to whom this process should offer benefits and development as they assume their respective responsibilities, singly and collectively. The breaking-down of borders is not simply a material fact: it is also a cultural event both in its causes and its effects. If globalization is viewed from a deterministic standpoint, the criteria with which to evaluate and direct it are lost. As a human reality, it is the product of diverse cultural tendencies, which need to be subjected to a process of discernment. The truth of globalization as a process and its fundamental ethical criterion are given by the unity of the human family and its development towards what is good. Hence a sustained commitment is needed so as to promote a person-based and community-oriented cultural process of world-wide integration that is open to transcendence. ${ }^{14}$ (emphasis added)

In May 2018, the Vatican issued its Oeconomicae et pecuniariae quaestiones: "Considerations for an Ethical Discernment Regarding some Aspects of the Present Economic-Financial System," which called for greater oversight and vigilance by public authorities to prevent such economic evils as fiscal evasion, financial mismanagement, unsurmountable public debt, and the increase of offshore accounts to hide financial assets. The text pillories the "profoundly amoral culture" of greed by financial agents and calls for Christians to make themselves "catalysts of a new social behavior, shaping our actions to the search for the common good, and establishing it on the sound principles of solidarity and subsidiarity." 
Similarly, international organizations of the so-called Christian left, such as the World Council of Churches (WCC), frequently speak to governments and policymakers about a Christian vision for an ecologically friendly and economically just global order. A current initiative of the WCC calls for adoption of policies supporting "small-scale, live-giving $[s i c]$ agriculture," "climate-friendly mobility," "ecological, fair, and regional" consumption, the creation of "places for moneyless interaction," and "just finance." Individual churches or church associations frequently attempt to use their influence with governmental officials or organizations to promote economic policies that they see as congenial to the message of the Gospel.

The church's force of moral suasion may exert some influence on policy formation among the political elites that set the rules for trade, regulation, banking, securities dealing, sovereign debt, and the like, but many Christian leaders are reluctant to come too close to the technocratic details lest they be perceived as becoming excessively political or overstepping the boundaries of their expertise. The Archbishop of Canterbury can call Brexit a "political," "practical," and "moral" failure, but, at the end of the day, the Church of England as an institution can do little more than urge five days of prayer for the poor affected by the economic disruption of British exit from the European Union. ${ }^{16}$ Meanwhile, many evangelical leaders in the United States are celebrating Brexit and related antiglobalist retrenchments as the just reassertion of national sovereignty and the rejection of an internationalism vehemently suspected of socialist and secularist leanings.

While Christian leaders frequently opine about the large political-economic questions of the day, there is scant evidence that their influence is seen in the important details of policy implementation. The reality is that the legal regulation of the international public order has become so specialized, complex, and insular that few lay people-including the church leaders with the largest bully pulpits - understand it very well. When experts at the Organisation for Economic Co-operation and Development (OECD) debate whether the Dynamic Stochastic General Equilibrium model or some alternative better predicts the interaction of world economies, it is unlikely that the perspectives of religious leaders will be seen as helpful. The heads of the elite economic organizations making the key policy decisions for the global economic system are just as likely to see religious leaders as forces of division and discord as moral forces to be harnessed in shaping economic policies. ${ }^{17}$

This is not to say that the technocratic decisions that shape the global economy are morally neutral. When banking regulators set liquidity thresholds in Basel, or antitrust regulators set the terms of global mergers in Brussels, or monetary officials determine acceptable sovereign debt levels in Belize, their technocratic assessments rest upon implicit value-laden judgments, but ones that even sophisticated lay people have little hope of comprehending. The growing tide of antiglobalism rests, at least in part, on the perception that consequential decisions that shape lives and destinies are being made by distant technocrats whose value systems and analytical tools reside in an impenetrable black box. Christian leaders 
have, thus far, shown no greater aptitude than anyone else at opening the black box.

\section{Grassroots Christianity around the globe}

If the church qua church has found itself largely excluded from the expert decision-making that shapes the formal economic order among nations, this is not to say that Christians have little influence in international markets or economic systems. To the contrary, the economic influence of individual Christians is as broad and international as the spread of Christianity itself, which, from its earliest days, has been on global mission to reach the farthest ends of the earth. Writing about Christianity and the global economic order, Paul Williams observes that "Christianity, like capitalism, is also a global order but one whose nature and function is quite different." ${ }^{18} \mathrm{He}$ further notes that "Christianity's indigenizing tendency," which allows cultures to develop their own syncretic versions of the faith, has made Christianity the world's largest religion without enabling the church to develop "a centralized global infrastructure in the way the world's largest firms have." ${ }^{19}$ Grass-roots Christianity infuses the world's economy without centralized management of any Christian institution.

Scholarly work suggests that the global missionary movement from the seventeenth century to the present had a significant effect on democratic, educational, social, and economic progress in the developing world, ${ }^{20}$ although missionaries may also have settled in locations that were already the most favorable for economic development. ${ }^{21}$ At present, there are an estimated 430,000 Christian international missionaries spreading the Gospel around the world. ${ }^{22}$ Many of these missionaries follow the example of the Apostle Paul as "tentmakers," pursuing an economic vocation or profession in their place of ministry and hence contributing to both spiritual and economic life. Increasingly in recent years, mission organizations have focused their efforts on the economic empowerment of the poor and oppressed. Initiatives such as microfinance to stimulate entrepreneurship among the needy, job training and employment initiatives for victims of coerced prostitution or human trafficking, and economic development projects for destitute villages are examples of missionary participation in the global economic order out a conscious commitment to serve both souls and bodies. ${ }^{23}$ Such initiatives can both contribute directly to economic justice by providing material aid to needy people and project a Christian message about the obligation to consider the needs of "the least of these" to decision makers in the economy more broadly. Beyond traditional missionary work, Christian NGOs like Catholic charities, World Vision, Compassion International, and the Salvation Army play a critical role in disaster relief and economic rehabilitation around the globe. ${ }^{24}$ Churches also play an important role as oases of stability, shelter, and liberty in tempestuous places across the globe, often providing relief and economic support for persons displaced by war and oppression.

The influence of globally mobile Christians does not stop with those working across borders on missions of economic charity. Christianity is spreading around 
the globe through the twin forces of migration and conversion. Globally, Christianity has roughly maintained its demographic "market share" over the last one hundred years - around a third of the world's people are nominal Christiansbut the distribution has shifted sharply. ${ }^{25}$ In 1910 , two-thirds of the world's Christians lived in Europe; today, that number has fallen to a quarter. ${ }^{26}$ About a third of all Christians live in the Americas, a quarter in sub-Saharan Africa, and an eighth in Asia and the Pacific. ${ }^{27}$ Christianity is so widespread and diverse that it lacks any geographical center, dominant political ideology, or consensus economic theory. But individual Christians and Christian communities are the backbone of many facets of the global economy. Christian entrepreneurs in both the developed and developing world have the potential to shape local and global business cultures on such matters as bribery and corruption, vocational calling, and fair labor practices. 28 The ideas, values, and practices that Christians bring to their businesses, employment relationships, and consumer choices shape the international economic order, whether consciously or unconsciously.

Economists often insist that they have no competence to say what something is worth, but only to identify what people are willing to pay for it. From an inductive perspective, the world's economic system is simply the revealed preferences of the billions of individuals who participate in markets, make investment decisions, buy and sell things, hire and fire, or start or close businesses. Whether they think about it or not, Christians have the power to shape the global economic order through the retail decisions they make about their time, money, and relationships. If the church universal were to develop a common economic identity and a common set of economic beliefs and practices, it could reshape the international system.

To give a concrete example, consider the popular "buy local" movement that encourages consumers to prefer locally grown or manufactured products over those produced at a distance. "Buy local" is surely not free from moral and spiritual implications. One could imagine a Christian consensus developing that Christians should demonstrate solidarity with their local communities by supporting the local economy. Conversely, one could equally well imagine a consensus developing to the effect that the Christian should have no greater affinity for the local farmer than for the farmer living half a world away-both being equally cast in the image of God and, perhaps, equally a brother or sister in Christ-and therefore should make consumption decisions on some other principle, such as comparative advantage, allocative efficiency, or output maximization. Adoption of either of these perspectives as a matter of Christian belief by the mass of Christians globally would do more to shape the global economy than any decisions of the World Bank or IMF.

But then we are back to where we started-the observation that the vast heterogeneity in social and economic beliefs and practices in global Christianity renders it virtually impossible to trace a distinctively Christian influence on the global economy. While some social science research suggests that highly religious consumers behave somewhat differently than others-for example, by making fewer impulse purchases and spending less of their discretionary income ${ }^{29}-$ such 


\section{Daniel A. Crane}

empirical work tends to identify the effects of strong religiosity of any kind rather than adherence to a particular set of theological commitments. Christians are undoubtedly shaping the international economic system through their retail decisions, but whether their revealed preferences exhibit an identifiable set of distinctive patterns is doubtful. Jesus said that his disciples would be known by their fruits; alas, it would be challenging to identify the fruits of Christian participation in markets.

\section{The corporatist global order}

Thus far, we have considered the influence of Christian thought on economic structures, Christian organizations in dialogue with governmental decision makers, and grassroots Christianity participating directly in markets. If none of these three angles has seemed to capture the potential for a distinctive Christian influence on the global economy, that may be because the keys to the power structure moving the global economy are now held not by governmental technocrats or local politicians but by the top shareholders and managers of a few large multinational corporations. Firms like Google, Facebook, Amazon, and Apple hold immense power to reshape the world's business, the goods and services people buy, the information people receive, and how they connect with others. International banks drive monetary policy, conglomerated pharmaceutical companies make the critical investment decisions that can mean life or death for vulnerable populations, and individual wealth and security is often bound up in the vagaries of the stock market. Populists decry the power of these new "robber barons," the European Union issues ever more dramatic monetary sanctions for ostensible abuses of corporate power, and politicians call for their break up, but the power and influence of the largest corporations seems to grow unabated.

Consider the following: in a series of increasingly stern decisions from 2017 to 2019 , the European Union fined Google $\$ 9.3$ billion for violating European Union competition law principles. As large as that amount may seem, it did not even reach ten percent of the firm's annual revenue. Standing alone, Google's market capitalization exceeds the annual GDP of all but six European Union member states. The combined market capitalization of Google, Facebook, and Amazon exceeds the annual GDP of any member state. Throw in Microsoft and Apple, and the combined market capitalization of a few American technology firms quickly starts approaching the GDP of the entire European Union. However hard the European Union or other players in the global economic order might fight to catch up, the genie is out of the bottle. Large corporate players have such an embedded economic advantage that countervailing regulatory forces can only hope to smooth the roughest edges of a global system dominated by for-profit business firms.

In what is perhaps a recognition that powerful corporations are inevitably here to stay, legal systems have increasingly anthropomorphized the corporation in an attempt to give them human agency and humane responsibility. Criminal liability, once the exclusive pitfall of the natural person, has now migrated on a large scale 
to the corporation itself. ${ }^{30}$ The corporation's soul can be judged in a criminal case. So too can the corporation's conscience be pricked through the activism of shareholders or consumers. Corporate social responsibility (CSR) is now all the rage, with efforts shifting from the hortatory to the legal, with jurisdictions increasingly considering formal measures to encourage corporations to "give back"- to show that they are ... human. For example, in recent years both India and China have moved toward mandatory CSR regimes that require corporations to give back to communities in various ways. ${ }^{31}$

Anticorporatists rail against the humanization of the corporation: how can an inanimate thing-a creature of the state-have a First Amendment or free speech right to purvey political messages? ${ }^{32}$ And then it turns out that a corporation may have not only free speech rights but also the right to express its religious conscience. ${ }^{33}$ Man was created in the image of God, and now the state has created the corporation in the image of man.

What role can individual Christians or the church play in a global economic system where extremely large corporations have assumed not only the power to shape entire markets but also the moral attributes of humans, including the expression of religious conscience? For Christians, the problem is not that corporations cannot act religiously, but that most assiduously avoid any explicit adoption of religious values. Unlike a family-owned business like Hobby Lobby, which won the corporate religious conscience case in the US Supreme Court, most corporate executives would blanch at the prospect of injecting any element of religion into the corporation's decision-making. Multinational corporations maximize their profits by appealing to everyone and offending no one-by assuming political correctness in their every marketing decision, corporate statement, and public presentation. The slightest provocation to some demographic group in an advertising campaign or product design in some remote corner of the world can lead to a global backlash, calls for a boycott, and plummeting quarterly earnings. The American fast food company Chik-fil-A has spent years running the gauntlet of boycotts and bans springing from its perception as a Christian-affiliated company purveying antigay hate. Although liberated by law to speak politically and religiously, the large multinational corporations running the world want nothing to do with religion, apart from insipid montages of ecumenicism during the holiday season. Even companies with controlling shareholders perceived as religiously devout, such as Walmart, have to issue "clarifications" that they have no policy against their employees wishing customers "Merry Christmas," so long as they use their best judgment and try not to offend anyone. ${ }^{34}$ Contrary to the perception that the US Supreme Court's recognition of corporate religious liberty rights augurs a broad shift toward corporate religiosity, the far more prevalent trend is corporate avoidance of anything touching on religion in order to avoid offending anyone.

The global corporatist order presents similar challenges to Christians as the rise of the secular state presented in the wake of the Enlightenment two centuries ago. The Enlightenment made the public sphere-the sphere of government-a secular space which religion could only behold at a distance. The separation of 


\section{6}

church and state was promised not to unduly restrict the influence of the church over human affairs, since the church could continue to operate in the private sphere-the sphere not occupied by government, including the world of business and commerce. But as the sphere of government has grown in tandem with a private sphere increasingly occupied and dominated by large corporations also working according to a strict secularist modus operandi, the share of the global sphere in which Christian values can be expressly deliberated and implemented has shrunk proportionately. When Christians ask for a voice in the legislature, they are often told that they should not impose their private beliefs in the political sphere; when they ask for a voice in a boardroom, they are again told to keep their private views out of business decisions that affect others who do not share Christian beliefs. With the political regulation of the global economic order largely committed to secularist technocrats and the economic heart of that order manned by secularist multinational corporations, from what quarter will a distinctive Christian influence on that order emerge? Obvious contenders are few.

\section{An agenda for relevance}

Faced with the daunting challenge of maintaining relevance to the management of the world's fragile economy, it is tempting for the church to cede the field and retreat to the spaces still ostensibly left open to its influence: personal piety, corporate worship, and acts of charity. That would be a tremendous mistake. Although Christians may not easily reach consensus on the content of a Christian economic worldview, it would be difficult to deny that the Bible contains an economic message, indeed that an economic message is central to the biblical worldview. In the Gospel accounts, Jesus teaches about money - its evils, opportunities, and responsibilities-more than almost any other topic. Most of his parables concern financial management and economic activity (e.g., tenants, talents, faithful servants, hidden treasure, fishing nets, lending practices, lost coins, squandered inheritances, unjust stewards, and the rich man and Lazarus). The early church modeled both shared ownership and individual enterprise. Christian thinkers across the ages have engaged intensively with economic questions: think Augustine on utility and function, Aquinas on just price theory, Luther on predatory commercial dealings, Calvin on work and the professions. The Christian tradition in economics arises not out of compulsion to interact with culture, but out of an abundance of biblical source material.

Though daunting, none of the obstacles to the church's relevance to the global economic order identified in this chapter is insurmountable. That there is no consensus Christian economic philosophy should not prevent Christian thinkers from articulating comprehensive blueprints for a just and efficient economic order grounded in a Christian worldview. The diversity in available perspectives should count as a feature, not a bug, of the big tent that is Christendom. The technical complexity of the political, legal, and bureaucratic public management of the world's economic order should not discourage Christians from participating in the channels of decision-making and, particularly, in expressing the 
core values that should drive analysis and decision. If Christians do not shape those values, others will, and not based on some "neutral" (although, of course, not truly neutral) conception of the good. Although grassroots participation by Christians in economic markets leaves little distinctive impression of a Christian philosophy of market participation, this shouk not discourage Christians from thinking about how their own retail economic decisions reflect their faith and shape their world. Marketing literature suggests that a small number of active consumers or users can shape entire markets, for better or for worse. ${ }^{35}$ Faith the size of a mustard seed can move mountains; a slightly larger number of Christian consumers, employers, employees, or entrepreneurs-acting forcefully on a shared moral vision-might reform the global economy. Finally, Christians should not be deterred by the increasing areligiosity of the global corporatist order from secking to influence the culture and decisions of the corporate behemoths that drive an increasing share of global economic activity. Unlike in the political sphere, the obstacle to religious influence on corporate decision-making is not legal or constiturional, but material and economic. Corporate managers respond with alacrity to financial incentives. Christians are shareholders and consumers too; they, too, have levers to pull.

It is difficult to feel much optimism about the finture of the global economic order, but Christians are enjoined from existential pessimism. Jesus promised tribulation in this world, but also commanded good cheer since he had already overcome the world. The Christian is called to cheerful faithfilness regardless of the odds. The global international order may never be Christian, but Christians must remain in it, if not of it.

\section{Notes}

1 See Turley.

2 See, generally, Stiglitz.

3 See, for example, Decock; Colish.

4 Pufendorf; Grotius.

5 Luther.

6 See Stark.

7 Mokyr, 229, 314.

8 See Becker, Pfaff, and Rubin.

9 See Gregg.

10 See Chamberlain.

11 See Temple.

12 Janz, 63.

13 Barro and McCleary.

14 See Benedict XVI, Caritas in veritate (emphasis added).

15 World Council of Churches.

16 "Church of England urges five days of prayer for the poor as Brexit looms," www.theguardian.com/uk-news/2019/feb/23/justin-welby-says-poorestface-biggest-risks-posed-by-brexit-uncertainty.

17 Marshall, 397.

18 See Williams.

19 Ibid. 
20 See Woodberry, who argues that conversionary Protestants "were a crucial catalyst initiating the development and spread of religious liberty, mass education, mass printing, newspapers, voluntary organizations, and colonial reforms, thereby creating the conditions that made stable democracy more likely."

21 See Jedwab, Meier, and Moradi. The authors collect much of the research on the economic effects of missionary expansion but also argue that some of the ostensible effects may be endogenous - missionaries went to locations that were already the best suited for economic development.

22 https://factsandtrends.net/2016/12/12/10-key-trends-in-global-christianityfor- $2017 /$.

23 See, for example, Freeman.

24 See Bush, Fountain, and Feener; see also Thaut.

25 Pew Forum.

26 Ibid.

27 Ibid.

28 See Wood and Heslam.

29 See Kurt, Inman, and Gino.

30 See Khanna.

31 See Afsharipour and Rana.

32 Citizens United v. FEC, 558 US 310 (2010).

33 Burwell v. Hobby Lobby Stores, Inc., 573 US 682 (2014).

34 "Clarification on Wal-Mart's Holiday Greeting," https://corporatc.walmart. com/_news_/news-archive/2005/12/01/clarification-on-wal-marts-holidaygreeting.

35 See Harrison and Kjellberg.

\section{Bibliography}

Afsharipour, Afra, and Shruti Rana. "The Emergence of New Corporate Social Responsibility Regimes in China and India." UC Daris Business Law Journal 14 (2014): 175.

Alan, Robert C. Global Economic History: A Very Short Introduction. Oxford: Oxford University Press, 2011.

Barro, Robert J., and Rachel McCleary. "Religion and Economic Growth." NBER Working Paper No. 9682, May 2003. www.nber.org/papers/w9682.

Becker, Sasha O., Steven Pfaff, and Jared Rubin. "Causes and Consequences of the Protestant Reformation." https://warwick.ac.uk/fac/soc/economics/research/ workingpapers $/ 2016 /$ twerp_1105_becker.pdf.

Benedict XVI, Pope. "Caritas in veritate." Encyclical Letter of the Supreme Pontiff. http://w2.vatican.va/content/benedict-xvi/en/encyclicals/documents/hf_benxvi_enc_20090629_caritas-in-veritate.html.

Bush, Robin, Philip Fountain, and R. Michael Feener. "Religious Actors in Disaster Relief: An Introduction." International Journal of Mass Emergencies and Disaster 33/1 (2015). www.ijmed.org/articles/667/download/.

Chamberlain, John. The Roots of Capitalism. Indianapolis, IN: Liberty Fund, 1977.

Clarke, John N., and Geoffrey R. Edwards, eds. Global Governance in the Twenty-First Century. Basingstoke: Palgrave Macmillan, 2004.

Colish, Marcia L. Medieval Foundations of the Western Intellectual Tradition 4001400. New Haven: Yale University Press, 1997.

Crane, Daniel A., and Samuel Gregg, eds. Christianity and Market Regulation. Cambridge: Cambridge University Press, forthcoming. 
Decock, Wim. "Martín de Azpilcueta." In Domingo and Martínez-Torrón, Great Christian Jurists in Spanish History.

Domingo, Rafael, and Javier Martínez-Torrón, eds. Great Christian Jurists in Spanish History. Cambridge: Cambridge University Press, 2018.

Freeman, Dena. "Pentecostalism and Economic Development in Sub-Saharan Africa." In The Routledge Handbook of Religions and Global Development, edited by Emma Tomalin. London: Routledge, 2015.

Gregg, Samuel. "Commercial Order and the Scottish Enlightenment: The Christian Context." In Christian Theology and Market Economics, edited by Ian R. Harper and Samuel Gregg, 43-59. Cheltenham: Edward Elgar Publishing Inc., 2008.

Grotius, Hugo. The Rights of War and Peace Including the Law of Nature and of Nations. Translated by A.C. Campbell. Washington, DC and London: M.W. Dunne, 1901.

Harper, Ian R., and Samucl Gregg, eds. Christian Theology and Market Economics. Cheltnham: Edward Elgar Publishing Inc., 2008.

Harrison, Debbie, and Hans Kjellberg, "How Users Shape Markets." htrps://jour nals.sagepub.com/doi/pdf/10.1 177/1470593116652004

Janz, Denis R. World Christianity and Marxism. New York: Oxford University Press, 1998.

Jedwab, Remi, Felix Meier, and Alexander Moradi. "The Economics of Missionary Expansion: Evidence from Africa and Implications for Development." Centre for the Study of African Economies. July 5, 2018. https://pdfs.semanticscholar.org/ ed4l/6084500b874309e962e65ce4cb3239951183.pdf.

Khanna, V.S. "Corporate Criminal Liability: What Purposes Does It Serve?" Harvard Law Review 109 (1996): 1477.

Krugman, Paul R., Maurice Obstfeld, and Marc Melitz. International Economics: Theory and Practice, Global Edition. 2nd ed. New York: Pearson, 2017.

Kurt, Didem, J. Jeffrey Inman, and Francesca Gino. "Shoppers with Strong Religious Beliefs Spend Less and Make Fewer Impulse Purchases." https://hbr. $\operatorname{org} / 2018 / 07 /$ shoppers-with-strong-religious-beliefs-spend-less-and-make-fewerimpulse-purchases.

Luther, Martin. "On Trading and Usury." In Works of Martin Luther. Philadelphia: A.J. Holman Company, 1915.

Marshall, Katherine. "Faith, Religion, and International Development." In Oslington, The Oxford Book of Christianity and Economics.

Mokyr, Joel. A Culture of Growth: The Origins of the Modern Economy. Princeton, NJ: Princeton University Press, 2018.

Oslington, Paul, ed. The Oxford Book of Christianity and Economics. Oxford: Oxford University Press, 2014.

Pew Forum. "Global Christianity: A Report on the Size and Distribution of the World's Christian Population." www.pewforum.org/2011/12/19/global-christi anity-exec/.

Pufendorf, Samuel. Political Writings. Edited by Craig L. Carr and translated by Michael J. Seidler. New York: Oxford University Press, 1994.

Stark, Rodney. The Victory of Reason: How Christianity Led to Freedom, Capitalism, and Western Success. New York: Random House, 2007.

Stiglitz, Joseph E. Globalization and Its Discontents. New York: W.W. Norton, 2002.

Temple, William. The Kingdom of God. London: The Macmillan Company, 1912.

Thaut, Laura C. "The Role of Faith in Christian Faith-Based Humanitarian Agencies: Constructing the Taxonomy." International Journal for Voluntary and Nonprofit 
Organizations 20 (2009): 319-50. https://link.springer.com/article/10.1007\% 2Fs11266-009-9098-8.

Tomalin, Emma, ed. The Routledge Handbook of Religions and Global Development. London: Routledge, 2015.

Turley, Steve. The New Nationalism: How the Populist Right Is Defeating Globalism and Awakening a New Political Order. Turley Talks, 2018.

Williams, Paul S. "Christianity and the Global Economic Order." In Oslington, The Oxford Book of Christianity and Economics.

Wood, Eric A.S., and Peter S. Heslam. "Faith and Business Practice Amongst Christian Entrepreneurs in Developing and Emerging Markets." www.scielo.org.za/ pdf/koers/v79n2/04.pdf.

Woodberry, Robert D. The Missionary Roots of Liberal Democracy. Washington, DC: American Political Science Association, 2012.

World Council of Churches. "Roadmap for Congregations, Communities, and Churches for an Economy of Life and Ecological Justice." March 11, 2019. www.oikoumene.org/en/resources/documents/wcc-programmes/diakonia/eco nomy-of-life/roadmap-for-congregations-communities-and-churches-for-aneconomy-of life-and-ecological-justice. 